\title{
God the Benefactor and His Human Clients in Rom. 5-8
}

\author{
MARCIN KOWALSKI \\ Institute of Biblical Studies, The John Paul II Catholic University of Lublin, Poland \\ e-mail:xmkowal@gmail.com \\ ORCID: 0000-0002-8732-6868
}

\begin{abstract}
Summary: The author applies the patron-client model to consider the relationship between God and man in Rom. 5-8. First, the model and its basic features are presented in the context of the Greco-Roman society, including its applicability to divinity. Next, the various elements of the model are traced in Rom. 5-8 (asymmetry, exchange of goods, personal relationship, favoritism, reciprocity, kinship language, honor and voluntary entrance). The article finishes with the advantages of reading Rom. 5-8 through the lens of the patron-client relationship.
\end{abstract}

KEYWORDS: Rom. 5-8, patron-client model, sociology, anthropology of culture

T

he relationship between God and man in Rom. 5-8 has already been investigated from many angles. What readers usually notice is the title of the "sons of God" and the notion of adoption (8:14-17.23) which seems to control the status of Christians in the chapters in question. Yet, the idea of sonship appears in Rom. 5-8 late, only in the last chapter of the section, and is presented by Paul in a very particular manner. The believers are already called the sons of God (8:14-17) and at the same time they wait for adoption as sons $(8: 23){ }^{1}$ On the other hand, in Rom. 5-8 Paul calls them slaves of God's righteousness $(6: 16.18 .20 ; 7: 6.25)$. How can the titles of sons and slaves be reconciled in Rom. 5-8? Another issue regards the debt that the believers owe to the Spirit (8:12). ${ }^{2}$ The Spirit grants them freedom (8:2), makes Christ present in their lives (8:9), guarantees their future resurrection (8:11), and intercedes for them before God (8:26). Taking into consideration the greatness of God's work in the Spirit, how can man ever repay Him? What is the meaning of the debt and

1 Cf. J.J.J. van Rensburg, "The Children of God in Romans 8”, Neot. 15 (1981) 139-179; S. Bénétreau, "Permanence de la symbolique familiale en Romains 8,18-30", ETR 87/2 (2012) 199-211.

2 Cf. D.J. Venter, "The Implicit Obligations of Brothers, Debtors and Sons (Romans 8:12-17)", Neot. 48/2 (2014) 283-302. 
how can the work of the Spirit be related to the ethical exhortations resounding in Rom. $6 ?^{3}$

In this paper, we argue that the social model of patron-client relationship applied to Rom. 5-8 can provide satisfying answers to the above questions. According to this model, God acts as a more-than-generous Benefactor who invites his human clients to the life-giving relationship with Him. In this perspective, the language of kinship, debt, and service finds its natural explanation. We shall first present the patron-client model in the context of the Greco-Roman society and we will identify the elements that are characteristic for it. Subsequently, we shall apply those elements to Rom. 5-8 to explain the interaction between divine and human agents, with a special focus on chap. 8 of the letter. The patron-client model will allow us to understand better how the relationship between God and man could be perceived by Paul and by his addressees in Rome.

\section{The Characteristics of the Patron-Client Relationship}

New Testament times were characterized by a high degree of socioeconomic stratification. ${ }^{4}$ A small elite group, consisting of 1 up to $5 \%$ of the population, controlled the $99 \%$ of economic and social resources, while the vast majority lived a modest, or poor by modern standards life. ${ }^{5}$ The majority group comprised peasants, merchants, small traders, artisans, slaves, freedmen, and freedwomen. According to contemporary research, it is from that echelon that

3 On that issue see H. Räisänen, "Das Gesetz des Glaubens (Röm. 3.27) und das Gesetz des Geistes (Röm. 8.2)", NTS 26 (1979) 101-117; B. Byrne, "Living out the Righteousness of God. The Contribution of Rom 6:1-8:13 to an Understanding of Paul's Ethical Presuppositions", $C B Q 43 / 4$ (1981) 557-581; H. Giesen, "Befreiung des Gesetzes aus der Sklaverei der Sünde als Ermöglichung der Gesetzeserfüllung (Röm 8,1-4)”, BZ 53/2 (2009) 179-211; J. Maston, Divine and Human Agency in Second Temple Judaism and Paul. A Comparative Study (WUNT II/297; Tübingen: Mohr Siebeck 2010) (chap. 3); V. Rabens, The Holy Spirit and Ethics in Paul. Transformation and Empowering for Religious-Ethical Life (WUNT II/283; Tübingen: Mohr Siebeck 2010) 203-241.

4 Cf. E.C. Stewart, "Social Stratification and Patronage in Ancient Mediterranean Societies", Understanding the Social World of the New Testament (ed. D. Neufeld - R.E. DeMaris) (London - New York: Routledge 2010) 156. For more, see W.A. Meeks, The First Urban Christians. The Social World of the Apostle Paul (New Haven: Yale University Press 1983) 53-55; C.A. (Louisville, KY: Westminster John Knox 1997) 91-96.

5 Cf. A. Batten, "Brokerage. Jesus as Social Entrepreneur", Understanding the Social World of the New Testament (ed. D. Neufeld - R.E. DeMaris) (London - New York: Routledge 2010) 169. Meeks speaks of less than one percent constituting the top ranks of the ancient population. Cf. Meeks, The First Urban Christians, 53. The author refers to R. MacMullen, Roman Social Relations, 50 B.C. to A.D. 284 (New Haven: Yale University Press 1974) 88-91. 
Christians recruited most of their members. ${ }^{6}$ At the bottom, there were still the so-called ptochoi, the no-status people, who could not support themselves and were destitute.

Disproportions and social seclusion necessitated the procurement of patronage for those that lacked key provisions for maintaining their status or livelihood. ${ }^{7}$ Tenuiores and humiliores, insignificant and humble, had to rely on some sort of patrons. The system of dependence was additionally strengthened by the deliberately static character of ancient society characterized by little upward mobility. Elites held tightly to their privileges and the socially disadvantaged tended to remain so. Finally, there was no middle class in antiquity as we define it now, an economically independent majority class of moderate to leisured economic levels. ${ }^{8}$ Thus, patronage presents itself as an indispensable tool to provide the access to the goods otherwise denied to the majority of population.

Dionysius of Halicarnassus (Ant. rom., 2.9.2-3) ascribes the establishment of the system to Romulus himself. Later authors like Seneca (Ben. 1.4.2) judged the exchange of favors and services (beneficia), which underlay the system of patronage, the glue of human society. Such an exchange eased the tensions and conflicts provoked by inequalities. ${ }^{9}$ One can even put forth the thesis, that the system of patronage and the power of reciprocity should be regarded as the elements binding the vast Roman Empire. ${ }^{10}$ The rise of the Empire marks also the

6 Cf. Osiek - Balch, Families in the New Testament World, 97. The scholarly consensus does not hold for the status of early Christians. Among those who portray them as a "socially pretentious" group with entrepreneurial spirit and sizeable wealth, see E.A. Judge, The Social Pattern of the Christian Groups in the First Century. Some Prolegomena to the Study of New Testament Ideas of Social Obligation (London: Tyndale Press 1960); R. Scroggs, "The Sociological Interpretation of the New Testament. The present State of Research", NTS 26/2 (1980) 164-179; Meeks, The First Urban Christians, 73; G. Theissen, The Social Setting of Pauline Christianity. Essays on Corinth (Philadelphia: Fortress Press 1982); A.J. Malherbe, Social Aspects of Early Christianity (Baton Rouge: Louisiana State University Press 1977) 31. Among others who emphasize the bleak material existence of early Christians churches, see J.G. Gager, Kingdom and Community. The Social World of Early Christianity (Englewood Cliffs, NJ: Prentice-Hall 1975) 96; J.J. Meggitt, Paul, Poverty and Survival (Edinburgh: T \& T Clark 1998) 99. The in-between position is advocated by B.W. Longenecker, "Socio-Economic Profiling of the First Urban Christians", After the First Urban Christians. The Social-Scientific Study of Pauline Christianity Twenty-Five Years Later (ed. T.D. Still - D.G. Horrell) (London - New York: Continuum 2009) 36-59.

7 Cf. Stewart, "Social Stratification and Patronage in Ancient Mediterranean Societies", 156.

8 Cf. Osiek - Balch, Families in the New Testament World, 93.

9 Cf. P. Garnsey - R.P. Saller, "Patronal Power Relations", Paul and Empire. Religion and Power in Roman Imperial Society (ed. R.A. Horsley) (Harrisburg, PA: Trinity Press 1997) 96.

10 Cf. Pliny the Younger, Paneg. 25.5; R.P. Saller, Personal Patronage under the Early Empire (Cambridge - New York: Cambridge University Press 1982) 3. On the system of benefactions that created the social consensus and contributed to strengthening the imperial ideology, see C. Ando, Imperial Ideology and Provincial Loyalty in the Roman Empire (Berkeley: University of California Press 2000) 175-205. 
two important changes that occurred in the system. The first one regarded the concentration of far more resources in the hands of Caesar and his household. It limited the number of patrons and made the access to the imperial court all the more valuable. The second change was the increase of the so-called collective clients, villages, cities, ethnic groups, or other types of associations. ${ }^{11}$

It is exaggeration to say, that the Roman emperors became the first source of benefits for their subjects. ${ }^{12}$ The acts of Caesars (beneficio imperatoris) defined the rulers as essentially good and capable of doing nothing but good deeds (beneficia). ${ }^{13}$ Suetonius (Tit., 8.1) reports an anecdote on Titus who being warned at dinner that he had done nothing for anybody that day, answered, "Friends, I have lost a day". In his Panegyricus, Pliny numbers the countless beneficia granted by Trajan: consulates, an emergency grain shipment to Egypt, entertainment, the establishment of courts more sympathetic to the people, citizenship grants, an extension of immunity from the inheritance tax, and public constructions. ${ }^{14}$ According to other sources, the rulers wield offices, senatorial magistracies and governorships, equestrian procuratorships and militiae, priesthoods, and staff positions in the imperial household, freedman status, gifts, privileges and permissions to return from exile. ${ }^{15}$ Pater patriae, although not eliminating other benefactors, was in power to grant any favor in his vast dominium.

What criteria help us to distinguish the patron-client relationship from other types of relations in antiquity? Drawing on the distinctions pointed by other scholars we can name several factors: ${ }^{16}$

(1) Asymmetry: The two participating parties are of unequal status.

(2) The reciprocal exchange of goods and services: Both patron and client offer each other different kinds of goods.

(3) A long-distance, personal relationship: Patronage tends to create an enduring bond between partners.

11 Cf. Stewart, "Social Stratification and Patronage in Ancient Mediterranean Societies", 159-160.

12 Cf. Garnsey - Saller, "Patronal Power Relations", 97-99.

13 Cf. Saller, Personal Patronage under the Early Empire, 34.

14 See Pliny the Younger, Paneg. 26-28 (congiaria), 29-32 (grain supplies), 34 (entertainment), 38 (tax relief), 51 (public constructions), 69, 71, 90 (public offices and honors).

15 Cf. Saller, Personal Patronage under the Early Empire, 42.

16 The comprehensive list with reference to other scholars can be found in J.H. Neyrey, "God, Benefactor and Patron. The Major Cultural Model for Interpreting the Deity in Greco-Roman Antiquity”, JSNT 27/4 (2005) 467-468. See also S.N. Eisenstadt - L. Roniger, Patrons, Clients, and Friends. Interpersonal Relations and the Structure of Trust in Society (Cambridge - New York: Cambridge University Press 1984) 48-49; B.J. Malina, "Patron and Client. The Analogy behind Synoptic Theology", The Social World of Jesus and the Gospels (London - New York: Routledge 1996) 143-145; A. Wallace-Hadrill (ed.), Patronage in Ancient Society (London - New York: Routledge 1989) 1-8; Saller, Personal Patronage under the Early Empire, 1; Stewart, "Social Stratification and Patronage in Ancient Mediterranean Societies", 158. 
(4) Favoritism: Clients hold special positions in the patron's social network and obtain a special treatment

(5) Reciprocity: The system creates reciprocal obligations and debts that must be paid.

(6) Kinship language: Patron and client remain in a father-son relationship.

(7) Honor: The relationship is based on the given honor and contributes to the achieved honor of both parties.

(8) Free decision: Patronage in most cases is entered into voluntarily (see however the manumissio and the patronage by conquest).

What can the patron and client offer each other? In case of benefactors, Dionysius of Halicarnassus (Ant. rom., 2.10.1) states that patrons explain to their clients their laws; they take care of them, just like fathers do for their sons with regard to money and contracts; they file suit on behalf of their clients and defend them against any charges. The beneficiaries, on the other hand, owed their benefactors gratitude and veneration; they saluted and honored them in public, and provided also all sorts of services they needed. Reciprocity, which characterizes the bonds of patronage, could be of triple nature: negative (high amount of self-interest), balanced, or generalized (altruistic, with no immediate expectation of repayment). ${ }^{17}$ Most importantly, the relationship between patron and client was sacred, and violating it was deemed as an act of the highest impiety and labeled as treason. ${ }^{18}$

\section{The Application of the Model to God and Man}

Several scholars successfully applied the patron-client model to biblical studies. John K. Chow studied the interaction between Paul and the Corinthian community through the lens of the patronage system, portraying Paul as challenged by some rich and powerful in the community. ${ }^{19}$ In a more recent monograph, Jonathan Marshall investigated the nature of social relationships in the Gospel of Luke and came to the conclusion that Jesus did not employ or criticize patron-client relations or patrocinium. ${ }^{20}$ More positive results were reached by other scholars studying

17 The types were drawn by M. Sahlins, Stone Age Economics (Chicago: Aldine-Atherton 1972) 193-196. They were subsequently adopted to biblical studies by Malina, "Patron and Client", 153-154; Neyrey, "God, Benefactor and Patron", 469; Stewart, "Social Stratification and Patronage in Ancient Mediterranean Societies", 157.

18 See Dionysius of Halicarnassus, Ant. rom., 2.10.3.

19 See J.K. Chow, Patronage and Power. A Study of Social Networks in Corinth (JSNTSup 75; Sheffield: Sheffield Academic Press 1992).

20 See J. Marshall, Jesus, Patrons, and Benefactors. Roman Palestine and the Gospel of Luke (WUNT II/259; Tübingen: Mohr Siebeck 2009). 
the model of patron and client in the Bible. In the articles by Bruce J. Malina ${ }^{21}$ and Jerome H. Neyrey ${ }^{22}$ the reader finds the basic elements of the model and its illustration from the Greco-Roman, Jewish and New Testament texts. Further, Zeba A. Crook, ${ }^{23}$ Ben Holdsworth, ${ }^{24}$ Ernest van Eck, ${ }^{25}$ and John S. Kloppenborg ${ }^{26}$ apply the model to Paul, the beneficiary of God, to Christ, and to other human agents. The above mentioned authors show that the patron-client model can be successfully used to describe not only the relations between the members of Christian communities, but also between God and man. Stewart rightly notices that this aspect is lacking in the analysis of the situation in Corinth by Chow. ${ }^{27}$ Paul, by emphasizing his servanthood, not only subverts the patron-client ties, but also brings the Corinthians to loyalty to their divine patron; he understands them to be a single group indebted to God.

Further, Malina argues that the concept of father applied to God in the New Testament does not refer to father in any actual first-century, Mediterranean social sense, and the kingdom of God simply means a community or a new kind of household.$^{28}$ Both terms envision God and his clientele bound up in the system of patronage. According to the author, the description of God we find in the Scriptures coincides with the basic characteristics of a patron, which, amongst others, comprise: interest in and talent for cultivating relations with strategic persons (Abraham, Isaac, Jacob); benefits drawn from relations (recognition, honor and subservience of Israel); staying ahead of competitors (disallowing any other gods); innovativeness; willingness to take risks (the people's practical and theoretical rejection of God's initiative). As the Creator and covenant God, Jahweh controls the first-order resources and hence can be readily understood as a patron.

Neyrey in his article on the issue further explains extent to which the term "benefactor" was applied to divinity in antiquity. ${ }^{29}$ The author examines a set of titles given to gods (king, father, savior, benefactor, creator, sovereign) all

21 See Malina, "Patron and Client", 143-175.

22 See J.H. Neyrey, “'Josephus' Vita and the Encomium: A Native Model of Personality”, JSJ 25/2 (1994) 177-206; Neyrey, "God, Benefactor and Patron”, 465-492; J.H. Neyrey, " 'I Am the Door' (John 10:7, 9). Jesus the Broker in the Fourth Gospel”, CBQ 69/2 (2007) 271-291.

23 Z.A. Crook, "The Divine Benefactions of Paul the Client", JGRChJ 2 (2001) 9-26.

24 See B. Holdsworth, "The Other Intercessor. The Holy Spirit as Familia-Petitioner for the Father's Filiusfamilia in Romans 8:26-27”, Andrews University Seminary Studies 42/2 (2004) 325-346.

25 E. van Eck, "When Patrons are not Patrons. A Social-Scientific Reading of the Rich Man and Lazarus (Lk 16:19-26)", HTS Theological Studies 65/1 (2009) 346-356.

26 E. van Eck - J.S. Kloppenborg, "An Unexpected Patron. A Social-Scientific and Realistic Reading of the Parable of the Vineyard Labourers (Mt 20:1-15)", HTS Theological Studies 71/1 (2015) http://dx.doi.org/10.4102/hts.v71i1.2883.

27 Stewart, "Social Stratification and Patronage in Ancient Mediterranean Societies", 164.

28 Malina, "Patron and Client", 147.

29 Neyrey, "God, Benefactor and Patron", 471-475. 
of which functioned in the context of patronage system. According to the ancients, deities could bestow on man a number of goods including distinction in the city, good will, power, good health, physical strength, and wealth ${ }^{30}$ Seneca (Ep. 95.48-49) stated that giving benefits is an essential characteristic of God, for which no further explanation is needed. Gods did not ingratiate themselves to men and their favors were not conditioned by any hope of gain. The human clients, being incapable of repaying gods in the manner that would match their gifts, were called to honor their divine patrons by showing them gratitude and by giving them praise. ${ }^{31}$

\section{The Patron-Client Relationship in Rom. 5-8}

No other letter seems to be more fit to analyze it in terms of patron-client relationship than the letter to the Romans. It was here, in the bustling capital city of the Empire, where one would look for powerful friends and brokers. It was here where familia caesaris was located with many freedmen and slaves taking care of the emperor's business. These images taken from everyday life might be especially appealing to the community in Rome. In what way the patron-client relationship can be reflected in Rom. 5-8? At the present stage, we shall verify the presence of the basic elements indicating the existence of the patronage model in the chapters in question, with a special focus on Rom 8 , where the relationship between God and man riches its climax in the gift of the Spirit.

\subsection{Asymmetry}

According to what was said above, several factors are instrumental in detecting the patron-client model present in the text. The first one is asymmetry by which we understand that the two parts involved in relationship are not of equal status. ${ }^{32}$ That fits perfectly the description of the relationship between God and man in Rom. 5-8. In Rom. 5:6.8.10 Paul states that God showed his grace to man while he/she was still weak ( $\dot{\alpha} \sigma \theta \varepsilon v \eta \dot{\zeta})$ and in a sinful condition. The language

30 Cf. Neyrey, "God, Benefactor and Patron", 477-480. See also Crook, "The Divine Benefactions of Paul the Client", 13.

31 See Philo, Plant. 31.130-131.

32 Cf. Saller, Personal Patronage under the Early Empire, 1; Eisenstadt - Roniger, Patrons, Clients, and Friends, 49; Malina, "Patron and Client", 144; Neyrey, "God, Benefactor and Patron", 467; Stewart, "Social Stratification and Patronage in Ancient Mediterranean Societies", 158. 
of abundance which dominates in Rom. 5:15.20 is contrasted by the Adamic condition of $\sin$ and death. ${ }^{33}$ The believers were once the slaves of sin, and now they are to become the slaves of righteousness (6:17-18). They still experience

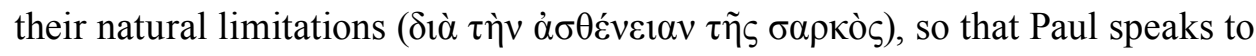
them in human terms urging them to yield their members to righteousness (6:19). The most impressive image of disparity between man and God is the tragic cry of man's ego torn between the desire and inability to do good (7:7-25). ${ }^{34}$

Although the situation described in Rom. 8 changes significantly, man is still presented as standing at the crossroads between life and death, dependent on whether he chooses the body or the Spirit to guide him (8:5-8). ${ }^{35}$ Man's body is subject to death (8:10-11) and suffering (8:17-18; cf. also 5:3), participating in the groaning of creation, and waiting for its final redemption $(8: 23) .^{36}$ God, in congruence with the narratio (Rom. 5:17-18) and the thesis (5:21), is the one who grants eternal life and raises the mortal human body from death $(8: 11.13) .^{37}$

Next, the allusion to sonship itself, even though used in a metaphorical way with the special stress on freedom, brings to mind inequality that exists in the

33 Cf. J.M.G. Barclay, Paul and the Gift (Grand Rapids, MI: Eerdmans 2015) 495.

34 On Rom. 7.7-25, see especially W.G. Kümmel, Römer 7 und Das Bild des Menschen im Neuen Testament. Zwei Studien (Theologische Bücherei 53; München: C. Kaiser 1974); J. Lambrecht, The Wretched "I" and Its Liberation. Paul in Romans 7 and 8 (Louvain Theological \& Pastoral Monographs 14; Louvain: Peeters 1992); M.A. Seifrid, "The subject of Rom 7:14-25", NovT 34/4 (1992) 313-333; Maston, Divine and Human Agency in Second Temple Judaism and Paul, 127-152; J.-N. Aletti, "Romans 7:7-25 and Galatians 5:17. Questions and Proposals", New Approaches for Interpreting the Letters of Saint Paul. Collected Essays: Rhetoric, Soteriology, Christology and Ecclesiology (Subsidia Biblica 43; Roma: Gregorian \& Biblical Press 2012) 79-109.

35 On the creation that still belongs to the realm of Adam, see J.H. Lee, Paul's Gospel in Romans. A Discourse Analysis of Rom. 1:16-8:39 (Linguistic Biblical Studies 3; Leiden - Boston: Brill 2010) 410 (with reference to Rom 8:18-30).

36 On the groaning of creation which reveals mankind's weakness, distance from the goals to be achieved, and imperfect state, see R.J. Dillon, "The Spirit as Taskmaster and Troublemaker in Romans 8", CBQ 60/4 (1998) 699; J.R. Dodson, The "Powers" of Personification. Rhetorical Purpose in the book of Wisdom and the Letter to the Romans (BZNW 161; Berlin - New York: Walter de Gruyter 2008) 174; J.A. Fitzmyer, Romans. A New Translation with Introduction and Commentary (AB 33; New York: Doubleday 1993) 509-510.

37 On the points of contact between Rom. 5 and 8 in the context of rhetorical dispositio, see J.-N. Aletti, "Romans 5-8. The Arrangement and Its Theological Relevance", New Approaches for Interpreting the Letters of Saint Paul. Collected Essays: Rhetoric, Soteriology, Christology and Ecclesiology (Subsidia Biblica 43; Roma: Gregorian \& Biblical Press 2012) 72, 74; J.-N. Aletti, "Romans 8. The Incarnation and Its Redemptive Impact", New Approaches for Interpreting the Letters of Saint Paul. Collected Essays : Rhetoric, Soteriology, Christology and Ecclesiology (Subsidia Biblica 43; Roma: Gregorian \& Biblical Press 2012) 111-113; A. Gieniusz, Romans 8,18-30. Suffering Does Not Thwart the Future Glory (USFSJH 9; Atlanta, GA: Scholars 1999) 40-50. 
Roman law between the paterfamilias and his progeny (8:14). ${ }^{38}$ Finally, in Rom. 8:26 Paul mentions the weakness ( $\dot{\alpha} \sigma \theta \dot{\varepsilon} v \varepsilon 1 \alpha)$ of the sons of God that has to be remedied by the intercession of the Spirit. Fee is probably right here, reading weakness in the context of the sufferings mentioned by Paul in Rom. 8:17-18. ${ }^{39}$ Interestingly, the vocabulary of weakness in Paul and in the Greco-Roman world also denotes humble status and lower position of those who call themselves clients of the potentiores. ${ }^{40}$ No matter the precise connotation of $\alpha \sigma \theta \varepsilon \dot{\varepsilon} \varepsilon 1 \alpha$ in Rom. 8:26, it stresses the difference between the fullness of life belonging to divine patron and the present condition of believers "caught between two ages."

\subsection{Exchange of Goods}

Patronage comprises the reciprocal exchange of goods and services, which are clearly differentiated in Rom. 5-8. God and man offer each other different kinds of goods, which also sets patronage off from friendship between equals. ${ }^{42}$

38 On the status of paterfamilias and children in the Roman law, see K. Cooper, "Closely Watched Households. Visibility, Exposure, and Private Power in the Roman Domus", Past and Present 197 (2007) 3-33; S.J. Joubert, "Managing the Household. Paul as Paterfamilias of the Christian Household Group in Corinth", Modelling Early Christianity. Social-Scientific Studies of the New Testament and Its Context (ed. P.F. Esler) (London - New York: Routledge 1995) 209-211; T.J. Burke, Adopted into God's Family. Exploring a Pauline Metaphor (New Studies in Biblical Theology 22; Nottingham - Downers Grove, IL: Apollos; InterVarsity Press 2006): 63-66; S. Dixon, The Roman Family (Baltimore: Johns Hopkins University Press 1992) 3-4, 36-53, 117; J.E. Grubbs, "Parent-Child Conflict in the Roman Family. The Evidence of the Code of Justinian", The Roman Family in the Empire. Rome, Italy, and Beyond (ed. M. George) (New York: Oxford University Press 2005); G.S. Nathan, The Family in Late Antiquity. The Rise of Christianity and the Endurance of Tradition (London - New York: Routledge 2000) 15-37.

39 See G.D. Fee, God's Empowering Presence. The Holy Spirit in the Letters of Paul (Peabody, MA: Hendrickson Publishers 1994) 579. Similarly R. Jewett - R.D. Kotansky, Romans. A Commentary on the Book of Romans (Hermeneia; Minneapolis: Fortress Press 2007) 522. Fitzmyer interprets weakness as mortality of the body and the tendency of the flesh which create the problem why human beings do not commune with God. Cf. Fitzmyer, Romans, 517. Dunn argues for "weakness" in the sense of the condition of man in this world, creaturliness. See J.D.G. Dunn, Romans 1-8 (WBC 38A; Dallas, TX: Word Books 1988) 477. The middle position (both sufferings and man's creaturliness) is taken by D.J. Moo, The Epistle to the Romans (The New International Commentary on the New Testament; Grand Rapids, MI: Eerdmans 1996) 523; Gieniusz, Romans 8,18-30, 212-214.

40 Cf. 1 Cor 1:25.27; 4:10; 8:7.8.9.10; 9:22; 12:22; Rom. 14:2; 15:1. On the sociological interpretation of weakness in Paul, see Theissen, The Social Setting of Pauline Christianity, 121-143; G. Theissen, "Social Conflicts in the Corinthian Community. Further Remarks on J.J. Meggitt, Paul, Poverty and Survival", JSNT 25/3 (2003) 371-391; Osiek - Balch, Families in the New Testament World, 94

41 See Jewett - Kotansky, Romans, 522.

42 Cf. Saller, Personal Patronage under the Early Empire, 1; Eisenstadt - Roniger, Patrons, Clients, and Friends, 48; Malina, "Patron and Client", 144; Neyrey, "God, Benefactor and Patron", 468; Stewart, "Social Stratification and Patronage in Ancient Mediterranean Societies", 158. 
God is the giver of justification and peace that comes through the Lord, Jesus Christ (5:1). Through Him also the believers obtained ( $\left.\dot{\varepsilon} \sigma \chi \eta^{\prime} \kappa \alpha \mu \varepsilon v\right)$ the access $(\pi \rho 0 \sigma \alpha \gamma \omega \gamma \eta)^{43}$ to the grace $(\chi \alpha ́ \rho ı)$ ) in which they now stand $(5: 2){ }^{44}$ Both the verbal forms and nouns imply the gracious decision to grant the access to the benefits of the heavenly ruler.

In Rom. 5:5, Paul mentions a double gift for the believers. The first part is

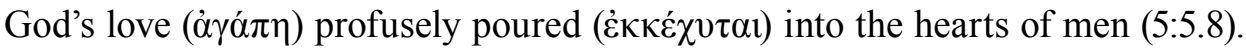
The second part is the Holy Spirit that mediates God's love, at the same time being himself a divine benefit ( $\delta 0 \theta \dot{\varepsilon} v \tau o \varsigma \dot{\eta} \mu \mathrm{i} v$ ). God also grants the believers the gift of reconciliation, reestablishment of the broken relationship ( $\alpha \alpha \tau \alpha \lambda \lambda \alpha \gamma \eta$ ) (5:11). The language of grace ( $\chi \alpha \dot{\alpha} \iota \varsigma)$, which is a free gift $(\chi \alpha \dot{\rho} \iota \sigma \mu \alpha)$ of Christ, reappears in in Rom. 5:15 presenting Jesus as a divine patron, with the language that reminds us of the Greco-Roman discussions on the altruism of gods. ${ }^{45} \mathrm{We}$ are dealing here with the generalized reciprocity that stresses the generosity of God, pouring out the abundance of grace, life and life-giving righteousness upon mankind, with no expectation of immediate repayment (5:15-21).

The exchange between God and man in Romans 8 comprises liberty, the Spirit, and the gift of sonship. For those who are in Christ, there is no condemnation (8:1), but freedom from sin and death brought by the law of the Spirit (8:2-4). He dwells in the believers and his power is instrumental in raising their mortal bodies (8:9-11). Christians received the Spirit of sonship in which they call God "Abba" (8:15), and the same Spirit bears witness with their own spirit that they are children of God (8:16). Amongst God's gifts for the believers envisioned in Rom. 8:17-24 one also finds the heritage and the future glory shared with Christ (8:17), the redemption of bodies (8:23) and the fullness of salvation (8:24-25).

In Rom. 8:28-29 Paul describes one more set of the gracious acts of God toward believers: the divine foreknowledge and predestination to be conformed to the image of his Son (8:29), the call, justification, and glorification (8:30). ${ }^{46}$ Finally, in the magnificent grand finale of Rom. 8:31-39, the apostle praises the astonishing generosity of the divine patron who did not spare his own Son, but gave Him up for all, signaling thus his will to grant $(\chi \alpha \rho i \zeta o \mu \alpha 1)$ everything to his "children" (8:32). Having the justification coming from God (8:33) and the

43 The noun can denote the access to God envisaged as an imperial figure. See Xenophon of Athens, Cyr., 7.5.45 (on the access to Cyrus for an audience).

44 On the language of grace in patron-client relationship, see Saller, Personal Patronage under the Early Empire, 21-30.

45 Cf. Neyrey, "God, Benefactor and Patron", 481-483.

46 According to Gieniusz, Romans 8,18-30, 287 in vv. 28-30 we are in the presence of the conclusio which amplifies the proposition $(8,18)$ and restates it in a positive way. Instead of the claim that suffering does not thwart future glory Paul admits that "God works with those who love him in everything for good" (v. 28). 
intercession of his Son (8:34), Christians can be sure that nothing will separate them from the love of their heavenly Benefactor (8:35-39).

There is no match for the gifts that the human clients receive from their loving patron. What can they offer God in exchange? ${ }^{47}$ What man offers ultimately belongs to God himself. ${ }^{48} \mathrm{He}$ can repay his Benefactor with faithfulness, dedication, and moral conduct, which we find in the exhortations resounding in Rom. $6-8{ }^{49}$ Since the duty of beneficiary is to praise his patron and to boast of his benefices, Christians boast in God through the Lord Jesus Christ in whom they received salvation and the assurance of future glory (5:11). Man honors God and shows loyalty to his divine patron also by bearing fruit for God and

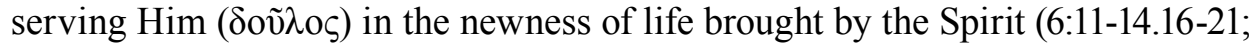
7:4-6). ${ }^{50}$ The newness of life, required as the badge of faithfulness to the divine patron, is actually synonymous to walking according to the Spirit (8:4). In case of the relationship between God and man, the notion of the exchange of goods overlaps with the notion of reciprocity, which will be discussed below. Clearly,

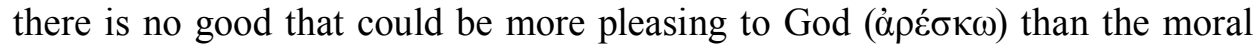
conduct of man (8:8). Ultimately, in the asymmetrical exchange, man offers God his all noble living. ${ }^{51}$

\subsection{Personal Relationship of Some Duration}

The bond between a patron and his clients can be described as a personal relationship characterized by longevity and endurance. ${ }^{52}$ It is different from any other commercial transaction in the marketplace. ${ }^{53}$ The relationship envisaged in Rom. 5-8 presents a strongly personal character as believers now call Christ "their" Lord (5:1) and bear God's love in their hearts (5:5). They were baptized into Christ, into his death and resurrection, to be raised with Him in a resurrection like his (6:3-5). ${ }^{54}$ This identification means the life of Jesus is reflected

47 For the same idea, see Philo, Decal., 10.41; idem, Spec. 1.30.152.

48 Cf. Philo, Spec., 2.35.219.

49 Cf. Rom 6:1-2.6.11-13.15.19; 7:4-6; 8:4-5.9.12-13.

50 On the various services offered by clients to patrons, see Dionysius of Halicarnassus, Ant. rom. 2.10.1-3.

$51 \quad$ Cf. Philo, Spec., 1.50.272.

52 Cf. Seneca the Younger, Ben. 2.18.5.

53 Cf. Saller, Personal Patronage under the Early Empire, 1; Eisenstadt - Roniger, Patrons, Clients, and Friends, 48; Neyrey, "God, Benefactor and Patron", 468; Stewart, "Social Stratification and Patronage in Ancient Mediterranean Societies", 158.

54 On eis in Rom. 6.3-4 which carries the notion of being a propriety, having a relationship, being incorporated in Christ, see Fitzmyer, Romans, 433; Dunn, Romans 1-8, 311; C.K. Barrett, The Epistle to the Romans (BNTC 6; London: Hendrickson $\left.{ }^{2} 1991\right) 114$. 
in the lives of his believers. It continues not only in this world, but also in the eschaton (6:9-10). The believers are to experience the same glory that the risen Lord enjoys with his Father (6:5.8). They are alive to God in Christ (6:11) ${ }^{55}$ By crucifying their old selves and dying with Christ they will surely live with Him (6:6.8). The bond that unifies God and man comprises both life and death. The relationship of belonging to God is so pervasive that Paul does not hesitate to use the language of slavery to describe it (6:18.22).

Another metaphor used by the apostle to express the strongly personal bond between God and the believers is the marital union whose image appears in Rom. 7:1-6. The believers, after their death to sin, belong now to another spouse, which is Jesus himself (7:4) ${ }^{56}$ They are in Jesus Christ (8:1) and the Holy Spirit dwells within them (8:9). The Spirit both helps and motivates the believers to walk in the newness of life and experience the future resurrection $(8: 9-11) .{ }^{57}$ Yet another metaphor that Paul employs to show the proximity between God, the Patron, and his human clients, is that of adoption. The believers are called sons of God and they can address God as "Abba, Father" (8:14-15). Together with the gift of sonship, they receive their share in the inheritance of the only son of God, Christ (8:17). The process of adoption, however, is still on its way, as it is testified by the groaning of creation, and it will reach its final stage only at the end times (8:22-23). ${ }^{58}$ The hymnal closing of Rom. 8:31-39 comes back to the theme of God's love with which Paul started in Rom. 5:5 to show it as a warranty of the eternal bond between the heavenly Patron and his clients. ${ }^{59}$

\subsection{Favoritism}

The patronage system by its nature serves to gain goods otherwise inaccessible for clients, the goods that "cannot be obtained in the market place at all". ${ }^{60}$ Favoritism

55 The expression "in Christ" denotes being united with the risen body of Christ, sharing in his life and glory. Cf. Fitzmyer, Romans, 438. Dunn underlines the meeting of divine power and human commitment in the Pauline expression "in Christ", which bring man to the quality of life that shares the character of Christ. The author also thinks of the foretaste of the "eschatological community" present here. See Dunn, Romans 1-8, 324.

56 On the freedom from the Law that implies the new obedience to Christ and the everlasting relationship with Him (cf. Rom. 6.9), see A. Gieniusz, "Rom 7,1-6: Lack of Imagination? Function of the Passage in the Argumentation of Rom 6,1-7,6", Bib. 74/3 (1993) 395, 398-400.

57 In the same vein in Philo God, the Benefactor, gives his graces and endows his believers with constancy to stay with them forever. Cf. Philo, Congr., 7.38.

58 Cf. Bénétreau, "Permanence de la symbolique familiale en Romains 8,18-30", 204-205.

59 On Rom. 8.31-39 and the everlasting bond between God and believer, see Moo, The Epistle to the Romans, 546-547; Dunn, Romans 1-8, 512-513.

60 Cf. Malina, "Patron and Client", 145-146, 149. See also Neyrey, "God, Benefactor and Patron", 468. 
between individuals of highly unequal status involves the exchange of favors and help of a qualitatively different sort, as we saw it above. It also makes a distinction between the ordinary people and the clients who are treated by the patron in a special way. The relationship with the patron assures them of the understanding and help that they need without begging for it. ${ }^{11}$ In antiquity, people might have objected that the emperor was showing favoritism to the wrong people, but they never objected in principle to favoritism. ${ }^{62}$ Thus, Marcus Aurelius was praised for his generosity, in part because he bestowed honores only on friends of suitable stations, while those of lower stations were rewarded with money. ${ }^{63}$

The language of gift (5:5.15.16.17; 6:23) and grace (5:20.15.17.20.21; 6:1.14.15), which are the hallmarks of favoritism, frequently appears in Rom. $5-8 .{ }^{64}$ Being justified by the blood of Christ, the believers are much more likely to be saved by Him from the wrath of God (5.9-10). United with Christ in a death like his, they will certainly be united with Him in a resurrection (6:5.8.22-23). Those who are in Christ incur no condemnation (8:1); they are freed from Law and death $(8: 2)$. They are called sons of God and co-heirs with Christ (8:14-17). They expect the future glory $(8: 18)$ and they experience the Spirit's intercession on their behalf (8:26). What is striking in this list is the superabundance of grace offered by God to the believers, with no special request from their part. ${ }^{65}$ God's Son gives up his life for the sinners and enemies of God, not for his righteous friends (5:6-8). Where sin increased, grace abounded even more (vं $\varepsilon \rho \pi \varepsilon \rho 1 \sigma \sigma \varepsilon v ́ \omega)(5: 20)$. Since Christ offered his life for the believers, there is nothing that he could deny them (8:3.32) ${ }^{66}$ The defense of the believers, their future salvation, and their share in the super victory of the Son (i $\pi \varepsilon \rho v i \kappa \alpha \omega)$ (8:37) are all signs of God's favoritism. ${ }^{67}$ Those who belong to Christ can expect the glory, inheritance, and resurrection without asking for the gifts, which pour out of God's generosity and the relationship he has with his people. Showing favoritism builds personal attachment and involves unexpected gifts. It is a celebration of relationship, just like in Rom. $5-8 .{ }^{68}$

61 Cf. Malina, "Patron and Client", 145, 149.

62 Cf. Saller, Personal Patronage under the Early Empire, 56.

63 Cf. Saller, Personal Patronage under the Early Empire, 45.

64 On the concept of gift underlying Pauline theology analyzed with the use of cultural anthropology, see Barclay, Paul and the Gift, 493-508.

65 On God, the Benefactor, nourisher and bountiful giver, see Philo, Congr., 30,171; QG 2,13 (the extraordinary abundance of God, the Benefactor's kindness and forgiveness).

66 On the superabundance of grace highlighted in Rom. 8:3.32, see Aletti, "Romans 8", 130; Gieniusz, Romans 8,18-30, 50-51.

67 On the verb $\dot{\pi \varepsilon \rho v i \kappa \alpha ́ \omega}$ which means "prevail completely", "to be more than a conqueror", "to win a decisive victory", see Hippocrates of Cos, Aphorisms, 87.9; Empedocles, D100; BDAG,

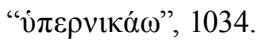

68 Cf. Malina, "Patron and Client", 149. 


\subsection{Reciprocity}

Reciprocity ethics are the sine qua non of patronal societies. ${ }^{69}$ This idea has already come to our attention when we analyzed the exchange of goods between God and man in Rom. 5-8. What we find in the letter to the Romans falls into the category of generalized reciprocity, which is characterized by God's altruism. There is no stress on immediate repayment from the part of man. Such a reciprocity had a tendency to be long-lived and passing from generation to generation. ${ }^{70}$ The category of generalized reciprocity emerges also in the ancient discussions on the nature of divine benefits. ${ }^{71}$ God is the one who gives out of his love and generosity, without entering his expenses in his ledger. ${ }^{72}$

In Rom. 5-8, Paul does not present God demanding a repayment for his graces. First, it would be impossible, considering the nature and abundance of his gifts. Second, the graces are being given freely by the benefactor with the only hope of benefiting the recipients. The response of faith and ethical life from the part of man, which resounds in Rom. 6:1-7:6 and Rom. 8:5-13, is not forced by God. ${ }^{73}$ They result from the patron-client relationship which naturally involves interpersonal obligation, personal loyalty and reciprocity. It is not fully contractual. ${ }^{74}$ Even if, according to the ancients, gods do not expect to be repaid, it is a duty of beneficiary to express gratitude. ${ }^{75}$ Otherwise, such a man can be charged with impiety and deserves death. ${ }^{76}$ In case of the benefits that cannot be formally repaid, Seneca advices simply to acknowledge the debt, show heart, be grateful to the benefactor, and match him in spirit. ${ }^{77}$

69 Cf. Saller, Personal Patronage under the Early Empire, 15. More on the use of the idea of reciprocity in biblical studies, see B.J. Malina, Christian Origins and Cultural Anthropology. Practical Models for Biblical Interpretation (Atlanta: John Knox Press 1986) 98-106; Neyrey, "God, Benefactor and Patron", 469-470.

70 Cf. Stewart, "Social Stratification and Patronage in Ancient Mediterranean Societies", 157.

71 Cf. Neyrey, "God, Benefactor and Patron", 481-483.

72 Cf. Seneca the Younger, Ben. 4.3.3; idem, Ep., 4.9.1.

73 On the ethical life empowered by the Spirit, see Rabens, The Holy Spirit and Ethics in Paul, 203-241. On the ethical implications that Paul draws in Rom 8.12-14 from the gift of the Spirit, see Gieniusz, Romans 8,18-30, 47.

74 Cf. Eisenstadt - Roniger, Patrons, Clients, and Friends, 48.

75 Cf. Pliny the Younger, Ep., 4.20. On the urgent need of a noble man to reciprocate the acts of kindness, see idem, Ep., 4.1.

76 Cf. Philo, Hypoth., 7.2; idem, Opif., 60.169; idem, Legat., 16.118. Seneca argues that ingrates are the worst of a very bad lot. See Seneca the Younger, Ben. 1.10.4; 1.1 .1 (the greatest vice of ungratefulness); 3.1.4-5 (ungratefulness to the benefactor as blindness and madness); 3.4.3-4 (sacrilege).

77 See Seneca the Younger, Ben., 2.35.3-5; 5.4.1; 6.29.2; 7.15.3-5; idem, Ep., 73.9-10. On the prayers that Pliny offers for Trajan's benefactions, see Pliny the Younger, Ep., 3.13. 
In the same vein, gratefulness toward God can be expressed either by deeds, words, good will or the disposition of heart. ${ }^{78}$ Thus, those who were baptized into Christ must consider themselves as dead to sin (6:11-14), living in conformity to Christ (6:6-8) and in absolute allegiance to the divine Patron. ${ }^{79}$ Rom. 7:1-6, which portrays man serving God in a natural way sums up the ethical requirements of Rom. 6 and foreshadows Rom. $8{ }^{80}$ Man pays his debt to his divine Benefactor by walking according to the Spirit (8:4.8-9). In the language that clearly alludes to the patron-client relationship, the believers are reminded of their obligation

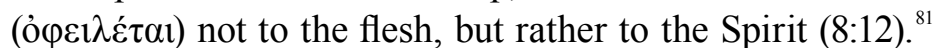

The debt owed to the Spirit can never be paid off. ${ }^{82}$ Instead, man is called to obey the Spirit by letting himself be led by Him (8:14), without falling back into the fear and mentality of slaves $(8: 15){ }^{83}$ Further, it is expected that those deemed worthy of God's benefactions give faith to the witness of the Spirit (8:16), show perseverance in suffering with Christ (8:25) and in love toward God (8:28). ${ }^{84}$ Praising God, the Benefactor, which Paul is doing in Rom. 8:31-39, also fulfills the just requirement of the relationship. ${ }^{85}$ The same was practiced by Abraham. ${ }^{86}$

\subsection{Kinship Language}

Both divine patronage and kinship relations rely on generalized reciprocity. ${ }^{87}$ No wonder then, that the family language appears in the description of the bond

78 Cf. Seneca the Younger, Ben., 6.29.2; 7.15.3-5.

79 On the moral commitment as the agenda of Rom. 6-7 and Paul's response to the charges that the Gospel produces lawlessness, see Dillon, "The Spirit as Taskmaster and Troublemaker in Romans 8", 687-688. On reciprocity and the nature of gift which creates new obligations and allegiances, see Barclay, Paul and the Gift, 497-498, 500.

80 On the rhetorical function of Rom 7.1-6, see Gieniusz, "Rom 7,1-6: Lack of Imagination?", 389-400. It looks back to Rom 6, illustrating the fact that the believers are not under the Law. In the same time, it introduces the audience to the fatal consequences of being under the Law, which Paul exposes in Rom 7.7-25.

81 On the language of debt found in connection with benefactions, see Pliny the Younger, $E p$., 3.6; Seneca the Younger, Ep., 73.9-10; 81.8 and 18-19; idem, Ben., 2.35.3-5; 3.1.4-5; 3.4.3-4; $5.4 .1 ; 6.42 .1 ; 7.16 .4$. On the Pauline argumentation in Rom 8,12 , see A. Gieniusz, "Debtors to the Spirit' in Romans 8.12? Reasons for the Silence", NTS 59/1 (2013) 61-72; Venter, "The Implicit Obligations of Brothers, Debtors and Sons (Romans 8:12-17)", 283-302.

82 Cf. Fee, God's Empowering Presence, 557.

83 See the same idea of man obeying God's commandments and thus reciprocating his benefactor in Philo, Alleg. Interp., 1.95-96.

84 On "loving God" as a response to his benefactions, see Philo, Spec., 1.55.299-300.

85 On praising God, the Benefactor, see Philo, Congr., 18.97; idem, Spec., 1.38.209; 1.50.272.

86 See Philo, Sobr., 11.58. Cf. also idem, Plant. 20.87-88. Loving and being loyal to God as Benefactor takes away the fear of God's sovereignty. Cf. idem, Plant. 21.90.

87 Neyrey, "God, Benefactor and Patron", 468; Stewart, "Social Stratification and Patronage in Ancient Mediterranean Societies", 157. 
between patron and client. ${ }^{88}$ The benefactor and beneficiary call each other respectively father and son, the names commonly applied to gods and men by Greeks and Semites. ${ }^{89}$ The kinship language also emerges in Rom. 5-8. God, the Father, is the one who by his glory raised Jesus from the dead (6:4). The title of son in Rom. 5-8 is applied in the first place to Jesus. He is the one sent by God (8:3), whose life was given up for sinners (8:32). The will of God is that the Son should be a model for every believer and the first among many brothers (8:29).

On the other hand, Christians are called sons of God (8:14) and endowed with the Spirit of sonship that encourages them to address God with the cry "Abba Father" (8:15). The same Spirit bears witness that they are children of God (8:16.17.21). The full meaning of sonship is yet to be revealed (8:19), as the believers are still waiting for the final adoption (8:23). A good deal of tension between "already" and "not yet" can be perceived in the Pauline description of the present status of believers. ${ }^{90}$ The sonship granted Christians by God is to be fully disclosed only at the end of times. There is an invitation to read it as a metaphor of salvation. ${ }^{91}$ All in all, the language of kinship indicates "the quality of commitment, solidarity or loyalty realized in terms of generalized reciprocity" between God and man, which fits the patron-client relationship. ${ }^{92}$

\subsection{Honor}

The patron-client relationship is naturally focused on honor and respect. ${ }^{93}$ Ancient benefactors were publically honored with statues, inscriptions and even temples dedicated to them by grateful clients. ${ }^{94}$ However, to be given special honors they must have performed the acts of voluntary patronage or payment of more than the obligatory gratuity. At that occasion, they were endowed with the titles of father, patriot, or the beautifier of the city. ${ }^{95}$ As mortals honored their earthly patrons, so they also praised the heavenly ones. Gods were extoled for their largesse by sacrifices, doxologies, thanksgivings, and simply by commitment to

88 Cf. Pliny the Younger, Paneg. 2, 4, 6, 9, 21, 26, 29, 39, 42, 53, 57, 67, 84, 87, 89.

89 Cf. Neyrey, "God, Benefactor and Patron", 472; Burke, Adopted into God's Family, 46-71; J.M. Scott, Adoption as Sons of God. An Exegetical Investigation into the Background of Huiothesia in the Pauline Corpus (WUNT II/48; Tübingen: Mohr Siebeck 1992) 3-60.

90 Cf. Fee, God's Empowering Presence, 571.

91 On the dynamic idea of sonship present here, see Gieniusz, Romans 8,18-30, 280.

92 Cf. Malina, "Patron and Client", 146.

93 Cf. Neyrey, "God, Benefactor and Patron", 468; P. Veyne - O. Murray - B. Pearce, Bread and Circuses. Historical Sociology and Political Pluralism (London: A. Lane, the Penguin Press 1990) 124-130.

94 Cf. Pliny the Younger, Ep., 3.8; 4.70.

95 Cf. Veyne - Murray - Pearce, Bread and Circuses, 124-125. 
them. ${ }^{96}$ God, whose love, generosity, and work of salvation is praised in Rom.

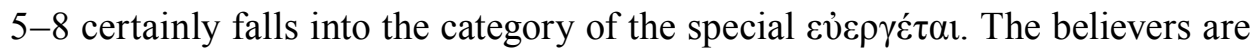
to honor Him by their commitment to the new order He establishes $(6: 1.15 ; 7: 4$; 8:9-13). Twice also Paul intones a thanksgiving for the benefits received by the believers from God, first in Rom. 7:24 when he thanks God for his Son Jesus Christ, who delivered him from the body of death. ${ }^{97}$ The second hymn of praise appears in Rom. 8:31-39 and resembles the statue that the apostle erects for the divine Benefactor at the end of his whole discourse on the newness of life in Rom. $5-8 .^{98}$

\subsection{Voluntary Entrance}

Finally, the patronage relations, according to the majority of scholars, are characterized by the fact that they are entered into voluntarily by both interested parties. ${ }^{99}$ This picture should be viewed through the analysis of Claude Eilers who differentiates two ways in which the patron-client relations are established. On the individual level, free clients gain their patrons willingly, yet the freedman are left no choice about having their former masters as patrons. We can see the same pattern in case of communal arrangements. The city can ask an individual to become its benefactor, or it receives a patron by virtue of conquest or colonial foundation. ${ }^{100}$ It means that patron-client bond can be stablished both in a voluntary and involuntary way. Which way is it established in Rom. 5-8?

Ben Holdsworth argued for the presence of the idea of manumission in the analyzed text. ${ }^{101}$ The vocabulary of freedom and liberation appears in Rom.

96 Cf. Neyrey, "God, Benefactor and Patron", 485. On Moses and other men honoring God, the Benefactor, with the willing disposition of their hearts, with hymns of thanksgiving and worship, see Philo, Mos., 2.46.156; idem, Spec., 1.50.272; idem, $Q G$ 2.50. In the same way, God honors man by accepting his sacrifices. See idem, $Q G, 2.53$.

97 On the role of Rom. 7:24 as an anticipation of what will be exposed in Rom. 8, see Moo, The Epistle to the Romans, 466-467.

98 On the thanksgiving in Rom 8:31-39 that plays the role of the rhetorical peroration to Rom. 5-8, see Aletti, "Romans 8", 112; Gieniusz, Romans 8,18-30, 49-51. On the passage in question, see also G. Schille, "Die Liebe Gottes in Christus. Beobachtungen zu Rm 8,31-39", ZNW 59 (1968) 230-244; A.H. Snyman, "Style and the Rhetorical Situation of Romans 8. 31-39", NTS 34 (1988) 218-231; O. Wischmeyer, "Beobachtungen zur Gedankenwelt von Römer 8,31-39", The Letter to the Romans (ed. U. Schnelle) (BETL 226; Leuven - Walpole, MA: Peeters 2009) 799-809.

99 Cf. Malina, "Patron and Client", 144; Stewart, "Social Stratification and Patronage in Ancient Mediterranean Societies", 158.

100 Cf. C. Eilers, Roman Patrons of Greek Cities (Oxford Classical Monographs; Oxford - New York: Oxford University Press 2002) 36.

101 See Holdsworth, "The Other Intercessor", 327-336. 
6:18.22, where Paul speaks of the believers who, having been set free from sin, have now become the slaves of righteousness and the slaves of God. Further, they are described as those who were set free from the Law of sin and death by the law of the Spirit $(8: 2)$. There is one more liberation awaited by the entire created world, namely, the liberation from its bondage to decay, which will take place in the end times $(8: 21)$.

Judging by the reported fragments, the believers in Rom. 5-8 could be perceived as the freedman of God, liberated from the bondage of sin. The Spirit would be understood here as an agent of liberation, acting on the slave's behalf. ${ }^{102}$ Manumission not only brought freedom to a released slave, but also established between him and his former master a new relationship of patronage analogous to the relationship between father and son. Since the manumission was the act of gratia, the libertus, even after having gained freedom, still remained attached to his master owing him honor and services. ${ }^{103}$ If we picture in these terms the relationship between God and man in Rom. 5-8, it would be then entered into involuntarily.

The problem with applying the model of manumission to Rom. 8 is that the former masters of believers are sin and death, not God. It is hard to speak of manumission, when mankind, as depicted in Rom. 6 and in Rom. 7:7-25, still suffers under the yoke of Law, sin, and death. God enters the scene as the redeemer who liberates mankind from the power of its former tyrannical masters. Besides, in the patron-client relationship, the patron can also be called "master" ( $\delta \varepsilon \sigma \pi$ ó $\rceil \varsigma)$, thus putting his client in the position of servant. ${ }^{104}$ Accordingly, Paul describes Christians in Rom. 6:16.18.20 as slaves of righteousness.

Further, in the crucial places of the letter to the Romans, we come to know that the liberating power of God effectively reaches man's life through the act of faith. In Rom. 1:16-17, which is the propositio to the first four chapters, Paul states that the Gospel is the power for salvation for everyone who has faith. ${ }^{105} \mathrm{In}$ Rom. 3:21-22, which is the sub-propositio to 1:16-17, the apostle argues that the righteousness of God manifests itself apart from the law, through faith in Jesus Christ. ${ }^{106}$ The redemption and expiation coming through Him are received by

102 Cf. Holdsworth, "The Other Intercessor", 328.

103 Cf. Pliny the Younger, Ep. 3,11. For more on the slaves and freedmen in the Greco-Roman context, see Osiek - Balch, Families in the New Testament World, 74-82; A.M. Duff, Freedmen in the early Roman Empire (New York: Barnes \& Noble 1958); J.A. Glancy, Slavery in Early Christianity (Oxford: University Press 2002).

104 Cf. Neyrey, "God, Benefactor and Patron", 474.

105 On the propositio in Rom 1:16-17, see J.-N. Aletti, God's Justice in Romans. Keys for Interpretating the Epistle to the Romans (SubBi 37; Rome: Gregorian \& Biblical Press 2010) 39; Jewett - Kotansky, Romans: 135; Dunn, Romans 1-8: 37; Fitzmyer, Romans, 253.

106 Cf. Aletti, God's Justice in Romans, 67, 87-88. 
faith (3:25). The entire chap. 4, by giving the example of Abraham, stresses the importance of man's initiative encapsulated in the act of faith. ${ }^{107}$ Consequently, in Rom. 5:1 Paul will reaffirm the truth, that man obtains justification by faith. If Rom. 5-8 is read in unity with the first four chapters, as it should be, then faith can be regarded as the free decision of man to enter into the relationship of patronage with God.

\section{Conclusion}

The system of patronage seems to provide a model that best suits the description of the relationship between God and man in Rom. 5-8. What are the advantages of such a reading? First, it is fully compatible with the culture and social institutions of the firs century, when patronage was the backbone of the Roman society. Second, it defends the contemporary reader against the anachronistic understanding of the relationship between God and man through the lens of modern culture. The patron-client model portrays God and man not as partners, but as essentially unequal, which comes to view especially in the exchange of goods. Third, the system of patronage in a superb way depicts the generosity of God who invites man to a personal relationship characterized by longevity and endurance. The believers cherish a special status and receive the abundance of God's graces by the virtue of their relationship with Him. Fourth, the model does not eliminate the active role of man, who is called to serve God and to offer his own life in the exchange of goods. Reciprocity is a sacred obligation of the relationship between God and man, as it was in the patron-client relationship in antiquity. Praise, gratefulness, thanksgiving, attitude of spirit, and moral conduct are not just an addition to the relationship between man and God, but they are decisive for its fate. To honor God, the Patron, means to keep the relationship alive. This way also the patron-client model allows us to avoid the clash between the work of the Spirit and the ethical behavior of man.

Last but not least, the model helps us put together the titles of sons and slaves employed by Paul, which can simply indicate the position of humans as clients. The language of kinship in Rom. 8 finds its proper place in relation to patronage. All in all, the patron-client model can surface much more data in Rom. 5-8 than any other model. It provides Paul and his readers with a conceptual glue that holds together diverse materials in the argumentation of Rom. 5-8. Thus

107 Cf. L.T. Johnson, Reading Romans. A Literary and Theological Commentary (Macon, GA: Smyth \& Helwys 2001) 67-81; P. Basta, Abramo in Romani 4. L'analogia dell'agire divino nella ricerca esegetica di Paolo (AnBib 168; Roma: Pontificio Istituto Biblico 2007). 
it can be a valuable supplement to the rhetorical and theological readings of the passage in question, enriching it with the important insights coming from the socio-historical setting of the first century.

\section{Bibliography}

Aletti, J.-N., God's Justice in Romans. Keys for Interpretating the Epistle to the Romans (SubBi 37; Rome: Gregorian \& Biblical Press 2010).

Aletti, J.-N., "Romans 5-8. The Arrangement and Its Theological Relevance", New Approaches for Interpreting the Letters of Saint Paul. Collected Essays : Rhetoric, Soteriology, Christology and Ecclesiology (SubBi 43; Roma: Gregorian \& Biblical Press 2012) 61-78.

Aletti, J.-N., "Romans 7:7-25 and Galatians 5:17. Questions and Proposals", New Approaches for Interpreting the Letters of Saint Paul. Collected Essays: Rhetoric, Soteriology, Christology and Ecclesiology (SubBi 43; Roma: Gregorian \& Biblical Press 2012) 79-109.

Aletti, J.-N., "Romans 8. The Incarnation and Its Redemptive Impact", New Approaches for Interpreting the Letters of Saint Paul. Collected Essays: Rhetoric, Soteriology, Christology and Ecclesiology (SubBi 43; Roma: Gregorian \& Biblical Press 2012) 111-138.

Ando, C., Imperial Ideology and Provincial Loyalty in the Roman Empire (Berkeley: University of California Press 2000).

Barclay, J.M.G., Paul and the Gift (Grand Rapids, MI: Eerdmans 2015).

Barrett, C.K., The Epistle to the Romans (BNTC 6; London: Hendrickson ${ }^{2} 1991$ ).

Basta, P., Abramo in Romani 4. L'analogia dell'agire divino nella ricerca esegetica di Paolo (AnBib 168; Roma: Pontificio Istituto Biblico 2007).

Batten, A., "Brokerage. Jesus as Social Entrepreneur", Understanding the Social World of the New Testament (ed. D. Neufeld - R.E. DeMaris) (London - New York: Routledge 2010) 167-177.

Bénétreau, S., "Permanence de la symbolique familiale en Romains 8,18-30", Études Théologiques et Religieuses 87/2 (2012) 199-211.

Burke, T.J., Adopted into God's Family. Exploring a Pauline Metaphor (New Studies in Biblical Theology 22; Nottingham - Downers Grove, IL: Apollos; InterVarsity Press 2006).

Byrne, B., "Living out the Righteousness of God. The Contribution of Rom 6:1-8:13 to an Understanding of Paul's Ethical Presuppositions", Catholic Biblical Quarterly 43/4 (1981) 557-581.

Chow, J.K., Patronage and Power. A Study of Social Networks in Corinth (JSNTSup 75; Sheffield: Sheffield Academic Press 1992).

Cooper, K., "Closely Watched Households. Visibility, Exposure, and Private Power in the Roman Domus", Past and Present 197 (2007) 3-33.

Crook, Z.A., "The Divine Benefactions of Paul the Client", Journal of Greco-Roman Christianity and Judaism 2 (2001) 9-26.

Dillon, R.J., "The Spirit as Taskmaster and Troublemaker in Romans 8", Catholic Biblical Quarterly 60/4 (1998) 682-702.

Dixon, S., The Roman Family (Baltimore: Johns Hopkins University Press 1992).

Dodson, J.R., The "Powers" of Personification. Rhetorical Purpose in the book of Wisdom and the Letter to the Romans (BZNW 161; Berlin - New York: Walter de Gruyter 2008).

Duff, A.M., Freedmen in the early Roman Empire (New York: Barnes \& Noble 1958).

Dunn, J.D.G., Romans 1-8 (WBC 38A; Dallas, TX: Word Books 1988). 
Eilers, C., Roman Patrons of Greek Cities (Oxford Classical Monographs; Oxford - New York: Oxford University Press 2002).

Eisenstadt, S.N. - Roniger, L., Patrons, Clients, and Friends. Interpersonal Relations and the Structure of Trust in Society (Cambridge - New York: Cambridge University Press 1984).

Fee, G.D., God's Empowering Presence. The Holy Spirit in the Letters of Paul (Peabody, MA: Hendrickson Publishers 1994).

Fitzmyer, J.A., Romans. A New Translation with Introduction and Commentary (AB 33; New York: Doubleday 1993).

Gager, J.G., Kingdom and Community. The Social World of Early Christianity (Englewood Cliffs NJ: Prentice-Hall 1975).

Garnsey, P. - Saller, R.P., "Patronal Power Relations", Paul and Empire. Religion and Power in Roman Imperial Society (ed. R.A. Horsley) (Harrisburg, PA: Trinity Press 1997) 96-103.

Gieniusz, A., "Rom 7,1-6: Lack of Imagination? Function of the Passage in the Argumentation of Rom 6,1-7,6”, Biblica 74/3 (1993) 389-400.

Gieniusz, A., Romans 8,18-30. Suffering Does Not Thwart the Future Glory (USFSJH 9; Atlanta, GA: Scholars 1999).

Gieniusz, A., " 'Debtors to the Spirit' in Romans 8.12? Reasons for the Silence”, New Testament Studies 59/1 (2013) 61-72.

Giesen, H., "Befreiung des Gesetzes aus der Sklaverei der Sünde als Ermöglichung der Gesetzeserfüllung (Röm 8,1-4)”, Biblische Zeitschrift 53/2 (2009) 179-211.

Glancy, J.A., Slavery in Early Christianity (Oxford: University Press 2002).

Grubbs, J.E., "Parent-Child Conflict in the Roman Family. The Evidence of the Code of Justinian", The Roman Family in the Empire. Rome, Italy, and Beyond (ed. M. George) (New York: Oxford University Press 2005) 93-128.

Holdsworth, B., "The Other Intercessor. The Holy Spirit as Familia-Petitioner for the Father's Filiusfamilia in Romans 8:26-27", Andrews University Seminary Studies 42/2 (2004) 325-346.

Jewett, R. - Kotansky, R.D., Romans. A Commentary on the Book of Romans (Hermeneia; Minneapolis: Fortress Press 2007).

Johnson, L.T., Reading Romans. A Literary and Theological Commentary (Macon, GA: Smyth \& Helwys 2001).

Joubert, S.J., "Managing the Household. Paul as Paterfamilias of the Christian Household Group in Corinth", Modelling Early Christianity. Social-Scientific Studies of the New Testament and Its Context (ed. P.F. Esler) (London - New York: Routledge 1995) 208-218.

Judge, E.A., The Social Pattern of the Christian Groups in the First Century. Some Prolegomena to the Study of New Testament Ideas of Social Obligation (London: Tyndale Press 1960).

Kümmel, W.G., Römer 7 und Das Bild des Menschen im Neuen Testament. Zwei Studien (Theologische Bücherei 53; München: C. Kaiser 1974).

Lambrecht, J., The Wretched "I" and Its Liberation. Paul in Romans 7 and 8 (Louvain Theological \& Pastoral Monographs 14; Louvain: Peeters 1992).

Lee, J.H., Paul's Gospel in Romans. A Discourse Analysis of Rom. 1:16-8:39 (Linguistic Biblical Studies 3; Leiden - Boston: Brill 2010).

Longenecker, B.W., "Socio-Economic Profiling of the First Urban Christians", After the First Urban Christians. The Social-Scientific Study of Pauline Christianity Twenty-Five Years Later (ed. T.D. Still - D.G. Horrell) (London - New York: Continuum 2009) 36-59.

MacMullen, R., Roman Social Relations, 50 B.C. to A.D. 284 (New Haven: Yale University Press 1974). 
Malherbe, A.J., Social Aspects of Early Christianity (Baton Rouge: Louisiana State University Press 1977).

Malina, B.J., Christian Origins and Cultural Anthropology. Practical Models for Biblical Interpretation (Atlanta: John Knox Press 1986).

Malina, B.J., "Patron and Client. The Analogy behind Synoptic Theology", The Social World of Jesus and the Gospels (London - New York: Routledge 1996) 143-175.

Marshall, J., Jesus, Patrons, and Benefactors. Roman Palestine and the Gospel of Luke (WUNT II/259; Tübingen: Mohr Siebeck 2009).

Maston, J., Divine and Human Agency in Second Temple Judaism and Paul. A Comparative Study (WUNT II/297; Tübingen: Mohr Siebeck 2010).

Meeks, W.A., The First Urban Christians. The Social World of the Apostle Paul (New Haven: Yale University Press 1983).

Meggitt, J.J., Paul, Poverty and Survival (Edinburgh: T \& T Clark 1998).

Moo, D.J., The Epistle to the Romans (The New International Commentary on the New Testament; Grand Rapids, MI: Eerdmans 1996).

Nathan, G.S., The Family in Late Antiquity. The Rise of Christianity and the Endurance of Tradition (London - New York: Routledge 2000).

Neyrey, J.H., “'Josephus' Vita and the Encomium: A Native Model of Personality”, Journal for the Study of Judaism 25/2 (1994) 177-206.

Neyrey, J.H., "God, Benefactor and Patron. The Major Cultural Model for Interpreting the Deity in Greco-Roman Antiquity", Journal for the Study of the New Testament 27/4 (2005) 465-492.

Neyrey, J.H., “'I Am the Door' (John 10:7, 9). Jesus the Broker in the Fourth Gospel”, Catholic Biblical Quarterly 69/2 (2007) 271-291.

Osiek, C.A. - Balch, D.L., Families in the New Testament World. Households and House Churches (Louisville, KY: Westminster John Knox 1997).

Rabens, V., The Holy Spirit and Ethics in Paul. Transformation and Empowering for Religious-Ethical Life (WUNT II/283; Tübingen: Mohr Siebeck 2010).

Räisänen, H., "Das Gesetz des Glaubens (Röm. 3.27) und das Gesetz des Geistes (Röm. 8.2)", New Testament Studies 26 (1979) 101-117.

Sahlins, M., Stone Age Economics (Chicago: Aldine-Atherton 1972).

Saller, R.P., Personal Patronage under the Early Empire (Cambridge - New York: Cambridge University Press 1982).

Schille, G., "Die Liebe Gottes in Christus. Beobachtungen zu Rm 8,31-39", Zeitschrift Für die Neutestamentliche Wissenschaft 59 (1968) 230-244.

Scott, J.M., Adoption as Sons of God. An Exegetical Investigation into the Background of Huiothesia in the Pauline Corpus (WUNT II/48; Tübingen: Mohr Siebeck 1992).

Scroggs, R., "The Sociological Interpretation of the New Testament. The present State of Research", New Testament Studies 26/2 (1980) 164-179.

Seifrid, M.A., "The subject of Rom 7:14-25”, Novum Testamentum 34/4 (1992) 313-333.

Snyman, A.H., "Style and the Rhetorical Situation of Romans 8. 31-39", New Testament Studies 34 (1988) 218-231.

Stewart, E.C., "Social Stratification and Patronage in Ancient Mediterranean Societies", Understanding the Social World of the New Testament (ed. D. Neufeld - R.E. DeMaris) (London - New York: Routledge 2010) 156-166.

Theissen, G., The Social Setting of Pauline Christianity. Essays on Corinth (Philadelphia: Fortress Press 1982). 
Theissen, G., "Social Conflicts in the Corinthian Community. Further Remarks on J.J. Meggitt, Paul, Poverty and Survival", Journal for the Study of the New Testament 25/3 (2003) 371-391. van Eck, E., "When Patrons are not Patrons. A Social-Scientific Reading of the Rich Man and Lazarus (Lk 16:19-26)", HTS Theological Studies 65/1 (2009) 346-356.

van Eck, E. - Kloppenborg J.S., "An Unexpected Patron. A Social-Scientific and Realistic Reading of the Parable of the Vineyard Labourers (Mt 20:1-15)", HTS Theological Studies 71/1 (2015). van Rensburg, J.J.J., „The Children of God in Romans 8”, Neotestamentica 15 (1981) 139-179. Venter, D.J., "The Implicit Obligations of Brothers, Debtors and Sons (Romans 8:12-17)", Neotestamentica 48/2 (2014) 283-302.

Veyne, P. - Murray, O. - Pearce B., Bread and Circuses. Historical Sociology and Political Pluralism (London: A. Lane, the Penguin Press 1990).

Wallace-Hadrill, A. (ed.), Patronage in Ancient Society (London - New York: Routledge 1989).

Wischmeyer, O., "Beobachtungen zur Gedankenwelt von Römer 8,31-39", The Letter to the Romans (ed. U. Schnelle) (BETL 226; Leuven - Walpole, MA: Peeters 2009) 799-809. 